\title{
分布型河川シミュレーションモデルの 適用性向上に関する研究 \\ A STUDY ON THE IMPROVEMENT OF THE APPLICABILITY OF THE DISTRIBUTED RIVER SIMULATION MODEL
}

\author{
山下 三男1・市川 新 ${ }^{2}$ \\ Mitsuo Yamashita and Arata Ichikawa \\ 1学生会員 工修 福岡大学大学院 工学研究科（干808-0135 北九州市若松区ひびきの2-1） \\ 2 フェロー会員 工博 福岡大学大学院教授 工学研究科（テ808-0135 北九州市若松区ひびきの2-1）
}

\begin{abstract}
There are several commercial river water simulation models, with the progress of mathematical techniques for hydraulic calculation in open channel and pipeline. As a result, it is getting easier for engineers to model a river basin as a distributed model. But the problems are still left in application, such as, which is suitable for rainfall-runoff model for sub-basins, how to determine parameters with insufficient data, the lack of detailed cross sections of river beds and so on.

With a view to promote the applicability of the distributed model, the authors applied it to the Japanese mountainous river basin for continuous simulation including dry weather condition. The countermeasure for above problems are the application of SCS method for surface runoff model, the adoption of new interflow model, the conversion of hourly rainfall data into 5 minutes intervals, and the presumed triangular river cross sections and falling works. Based on these assumptions, the simulation results fairly agreed with the observed data. It means basic concept of this study is in the right way and applicable to any other basins.
\end{abstract}

Key Words : distributed model, surface runoff, inter flow, SCS method, continuous simulation

\section{1.はじめに}

洪水による被害，水資源の分配に関する紛争，湖沼の 富栄養化や飲料水源の污染といつた水をめぐる問題を解 決するためには，まず水循環に関する詳細な情報が公開 され，それらの情報に基づき利害関係者（s takeholders）の間で共通認識が形成されなければならない. そのため「ハイドロインフォーマティックス」（水管理 のための情報工学）というものが必要とされてきている 1).その中で，水循環の空間的およひ時間的な変動を情 報として伝えるためのツールとして分布型の水理・水文 モデルが重要な役割を果たすものとして期待されている.

開水路や管路における水理計算を，不定流の連続式と 運動方程式の連立方程式（Saint-Venant式）を完全に解 く形(Dynamic wave 法 $\left.{ }^{2}\right)$ で, 精度よく迅速に行え, かつ 操作が容易となっってきたことから、近年、欧米におい てはMIKE11,HECやInfoworks RSといった市販の分布型河 川シミュレーションソフトが広く利用されている. その 結果、流域内を小流域に分割する分布型の河川シミュ
レーションモデルの適用は容易になってきている.

しかしながら，これらのソフトを実際の，とくに日本 の河川流域に適用するにはいくつかの課題が残されてい る. 降雨流出を計算するサブモデルの選択, パラメータ を同定するためのデータの不足, 河道モデルを記述する ための横断面測量データの不足などである. とくに, 降 雨流出現象は主として表面流出, 植生等による遮断, 土 壌への浸透, 浸透した雨水の再流出としての中間流及び 基底流出の過程で構成されるが，これらは特定の流域の 気候, 地形, 地質, 植生や人的な活動によりその影響度 は大きく異なる. 市販の河川シミュレーションソフトで はこれらの変動に対して、簡単なモデルの中から選択す るか、独自に構築することになっている.

さらには，水中における污濁物質を追跡する水質シ ミュレーションでは, 雨天時のみでなく晴天時を含めた 長期の連続的な解析が必要である. また対象流域が大き い場合にはある地点では雨が降っていても, ほかの地点 ではまったく降雨がないというような降雨の分布性を考 慮する必要がある. そのため, 無降雨時や低流量時を含 めた「連続シミュレーション」が求められている. 


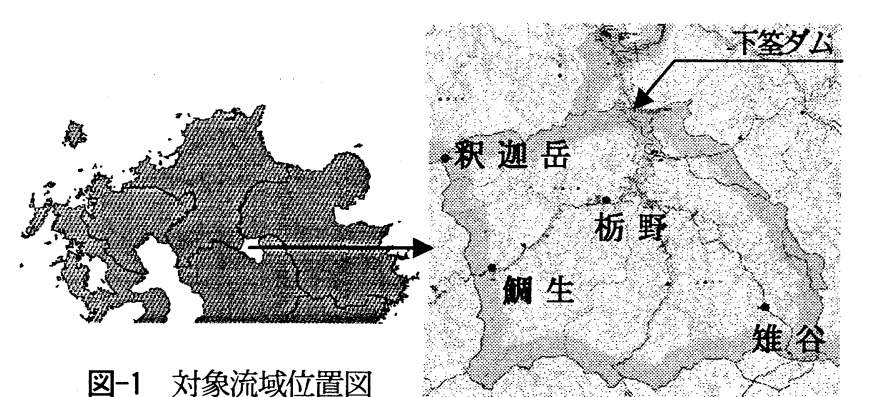

図-1 対象流域位置図

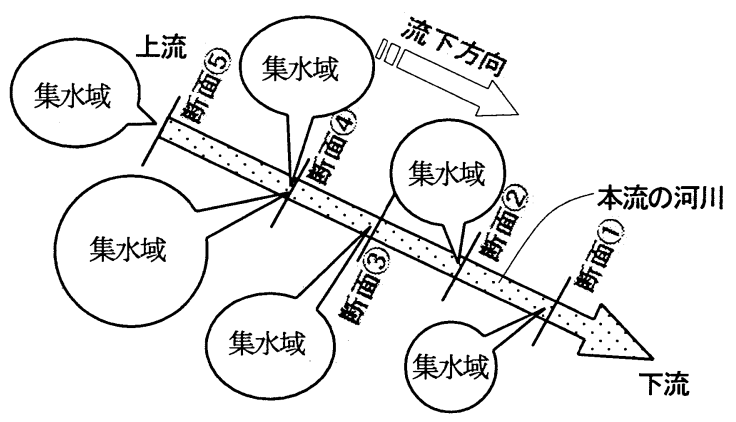

図-2＼cjkstart本研究における分布型モデルの概念

本研究はこれらの問題点を克服しながら, 分布型モデ ルである市販の河川シミュレーションソフトの適用性を 高めることを目標としている. そうすることにより，利 害関係者により詳細な情報を提供することが可能になる と考えている. 具体的には人工林に覆われた山地流域に, 分布型モデルである英国Wallingford社の河川シミュ レーションモデル「Infoworks RS」の適用を試み, 汎用 的な適用が可能となったので，ここに報告を行う.

\section{2. 適用対象流域}

モデル適用の対象は、筑後川の下筌ダム上流域の大分 県日田郡上津江村、中津江村である。流域面積は $182 \mathrm{~km}^{2}$ であり、位置を図-1に示す。2001年1月から 3 年間の鯛生、 杤野、雉谷、下鉒における時間降雨量と下鉒ダムの時間 流入量を国土交通省筑後川河川事務所、筑後川ダム統合 管理事務所から提供を受けたので解析の基礎資料として 使用した。また、釈迦岳における気象庁アメダスデータ も使用した.

\section{3. モデルの適用方法}

\section{（1）本研究における分布型モデルの概念}

本研究における分布型モデルの概念を図-2に示す.

まず，本流の河川を設定し，それに支流単位の小流域 からの流出ハイドログラフを境界条件として入力し, 本 流における流動追跡を行った. 小流域からの流出ハイド ログラフの推定については後述する集中型モデルを, 本 流における流動追跡については, 市販の河川シミュレー ションモデルのInfoworks RSを使用した.

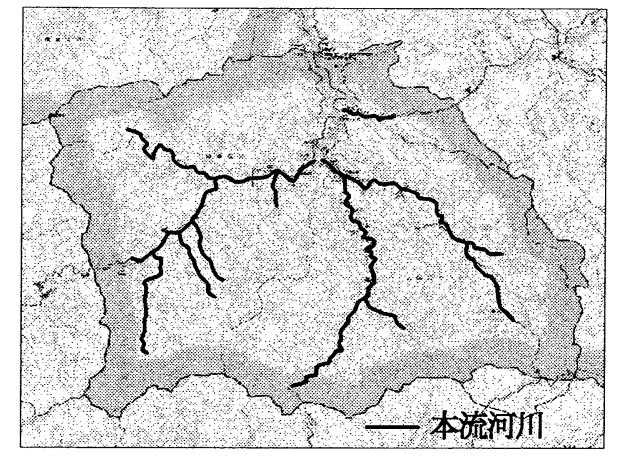

図-3＼cjkstart本流河川の設定

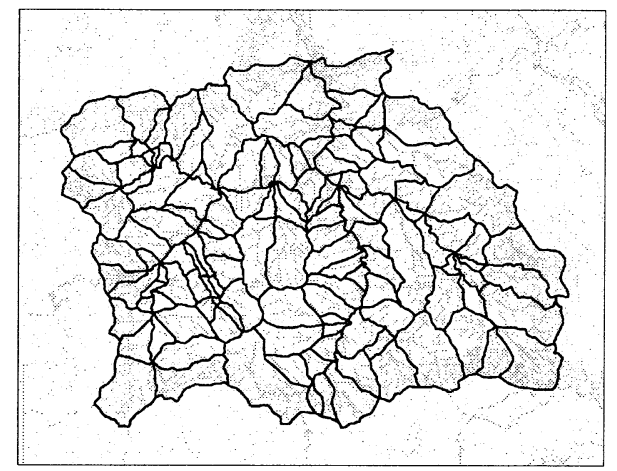

図-4＼cjkstart全体流域の小流域への分割

\section{（2）本流河川の設定}

まず，Infoworks RSを用いて流動追跡を行う対象とし ての本流河川を設定した（図-3）.

\section{（3）全体流域の小流域への分割}

次に，分布型モデルの基礎として，全体流域を支流を もとに129の小流域に分割した（図-4）. その結果，小 流域の平均面積は $1.4 \mathrm{~km}^{2}$ となった.

\section{（4）小流域からの流出ハイドログラフの推定}

各小流域からの流出ハイドログラフは表面流, 中間流 および基底流量からなるものとして，それぞれと小流域 全体のハイドログラフを集中型モデルで推定した. それ ぞれの集中型モデルについて以下に述べる.

\section{a）表面流モデル}

表面流モデルとして, 米国土壤保全局によって考案さ れたSCS法 (Soil Conservation Service Curve Number Method） ${ }^{3)}$ を採用した. その理由は，同法を適用するた めに必要なパラメータが（1），(2）式に表されるよう に, 許容最大貯留量 (S) のみであることと降雨の継続 に伴う流出係数の増大を連続的に表現している点にある （図-5参照）。

$$
\begin{aligned}
& \mathbf{P}=\mathbf{P}_{\mathbf{e}}+\mathbf{F}+\mathbf{I}_{\mathbf{a}} \\
& \mathbf{P}_{\mathbf{e}}=\frac{(\mathrm{P}-0.2 \mathrm{~S})^{2}}{\mathrm{P}+0.8 \mathrm{~S}}
\end{aligned}
$$

ここで, $\mathrm{P}$ ：累積降雨量 $(\mathrm{mm}), \mathrm{Ia}$ : 初期損失 $(\mathrm{mm})$, $\mathrm{F}$ ：累積浸透量 $(\mathrm{mm}) \mathrm{S}$ ：許容最大貯留量 $(\mathrm{mm}), \mathrm{Pe}$ ： 累積有効降雨量 (mm)である. 


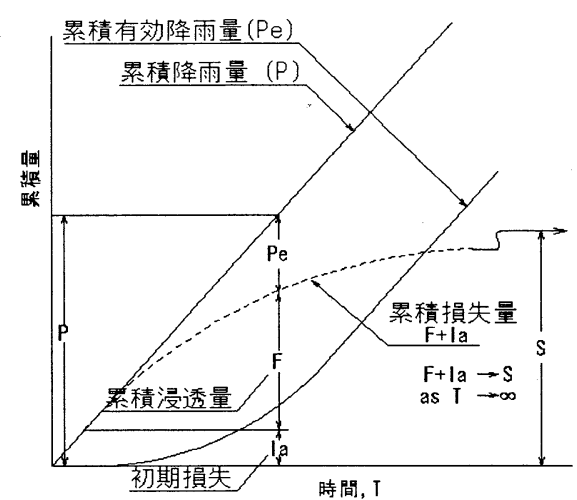

図-5 SCS法における降雨と有効降雨の関俰 （等降雨強度の雨が長時間継晩したと仮定した場合の概念図 ）

表-1 SCS法における先行降雨条件 ${ }^{5}$

\begin{tabular}{|c|c|c|}
\hline \multirow{3}{*}{$\begin{array}{c}\text { 降雨開始時の } \\
\text { 土壌の湿潤状態 } \\
\text { の類型 } \\
\text { (AMC) }\end{array}$} & \multicolumn{2}{|c|}{$\begin{array}{r}\text { 過去 } 5 \text { 日間の先行降雨の累積量 } \\
\text { P05:(mm) }\end{array}$} \\
\hline & 植物の休眠期 & 植物の生育期 \\
\hline & Dormant season & Growing season \\
\hline I (乾燥) & 13以下 & 36以下 \\
\hline II (標準) & $13 \sim 28$ & $36 \sim 53$ \\
\hline III（湿潤） & 28以上 & 53以上 \\
\hline
\end{tabular}

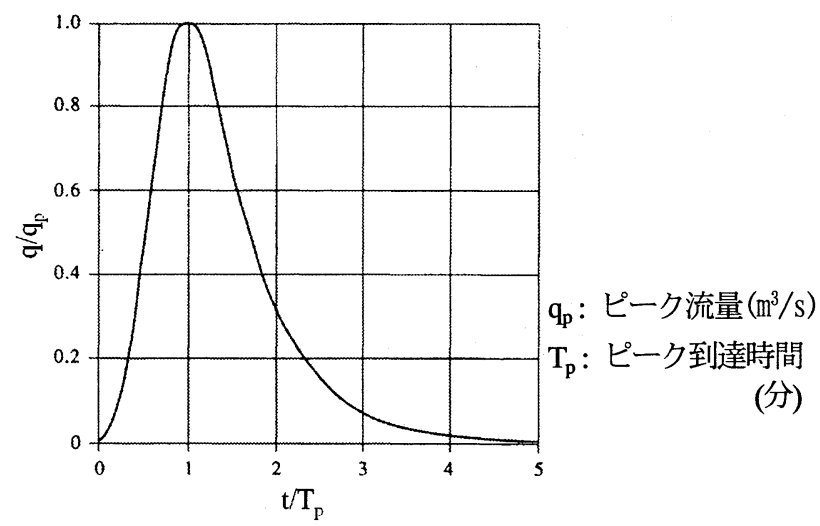

図-6 無次元単位図

(Dimensionless Unit Hydrograph) ${ }^{4)}$

土壌保全局では先行降雨条件（表-1）から, 土壤の湿 潤状態を3段階に分けることとなっているが，このよう な非連続な值を, 連続シミュレーション中の各降雨開始 時の值としてとることはできない，

そこで, Hor tonの浸透公式を変形した（3）式でその 值の変化を近似し ${ }^{6)}$ ，すべての降雨イベントの開始時に おける先行降雨量を求め, 降雨イベント毎の許容最大貯 留量を計算して自動的に更新できるようにすることによ り，連続シミュレーションに適用した。（図-7）

$$
\mathbf{S}=\mathbf{S}_{\mathbf{c}}+\left(\mathbf{S}_{\mathbf{o}}-\mathbf{S}_{\mathbf{c}}\right) \cdot \mathrm{e}^{-\alpha \cdot \mathbf{P}_{05}}
$$

ここで、So：最大貯留容量 $(\mathrm{mm}), \mathrm{Sc}$ ：最終貯留容量 (mm)， $\alpha$ : 減衰係数，P05：先行5日間の累積降雨量 (mm)である.

図-7の示すところは，仮に前日まで大量の降雨が あったとしても，翌日には Sc だけの浸透が可能にな ると仮定していることである．SCS法は（1），（2）式 を用いて降雨を有効降雨 $\mathrm{Pe}$ と損失雨量 $(\mathrm{F}+\mathrm{I}$ a $)$ に分離 するものであり, 求められた有効降雨に無次元単位図

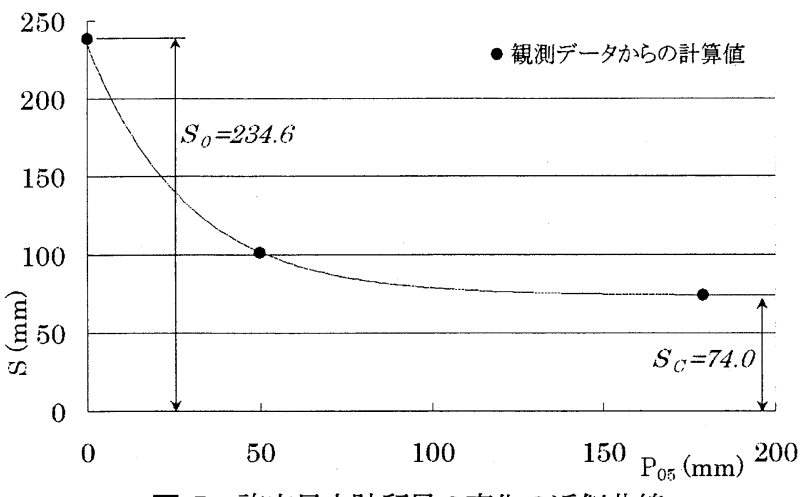

図-7 許容最大貯留量の変化の近似曲線

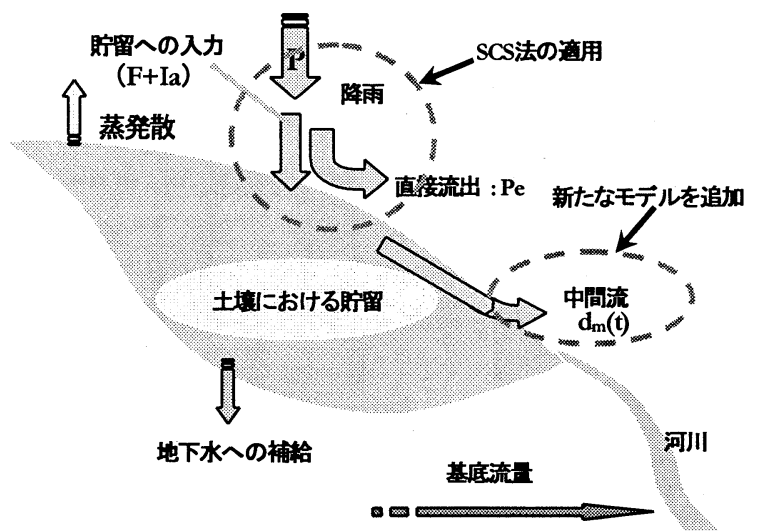

図-8中間流モデル（山下モデル）の概念

(Dimnsionless unit hydrograph ${ }^{4)}$ : 図-6) を適用して, 流量を求めた.

b) 中間流モデル

わが国の山地流域においては, 浸透する雨水が再流出 する中間流が, ハイドログラフに大きな影響を及ぼすた め), 新たな中間流モデル（山下モデル）を導入するこ ととした（図-8）.

このモデルでは, SCS法によって分離された損失雨量 （F+Ia）のうち，地下に浸透した一部が再流出するとし， 中間流の「有効再流出量 $\mathrm{dm}(\mathrm{t}) 」$ 」(4) 式を用いて算 出した. この「有効再流出量」はLinsleyの式 ${ }^{8)}$ (5)を応 用した中間流の単位図（図-9）によって流量に変換した.

$$
d_{m}(t)=k \cdot \frac{S_{c}}{S} \cdot \Delta\left(F+I_{a}\right)
$$

ここで, $\Delta\left(\mathrm{F}+\mathrm{I}_{\mathrm{a}}\right)$ : 累積損失量の変化量 $(\mathrm{mm}), \mathrm{k}$ : 中 間流配分定数, $\mathrm{Sc}$ : 最終貯留容量 $(\mathrm{mm}), \mathrm{S}$ : 許容最 大貯留容量 $(\mathrm{mm})$ である.

$$
\mathbf{T}_{\mathbf{r}}=0.8 \cdot \mathrm{A}^{0.2}
$$

ここで, $\mathrm{Tr}$ ：流出の終息時間 (日), A：集水面積 $\left(\mathrm{km}^{2}\right)$ である。

なお、中間流のピークは表面流出の終息時に到来する とし、そのピーク到達時間 $\mathrm{Tpm}$ を表面流のピーク到達 時間 $T_{p}$ との関係から(6)式で仮定した.

$$
\mathbf{T}_{\mathbf{p m}}=5 \times \mathbf{T}_{\mathbf{p}}
$$




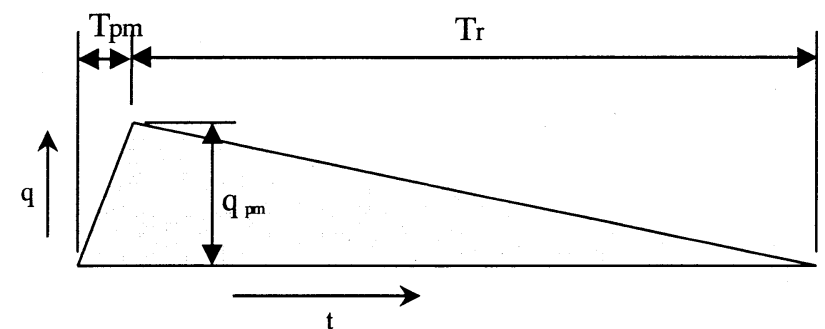

$\mathrm{Tpm}$ : 中間流のピーク到達時間

$\mathrm{q} \mathrm{pm}$ : 中間流のピーク流量

Tr : Linsleyの式(5)で定義される流出の終息時間

図-9 中間流の単位図

表-2 全体流域のパラメータ

\begin{tabular}{|c|l|c|}
\hline 記号 & \multicolumn{1}{|c|}{ 名 称 } & 値 \\
\hline So & 最大貯留容量 & $234.6 \mathrm{~mm}$ \\
\hline $\mathrm{Sc}$ & 最終貯留容量 & $74.0 \mathrm{~mm}$ \\
\hline$\alpha$ & 減衰係数 & 0.0352 \\
\hline $\mathrm{k}$ & 中間流配分定数 & 0.455 \\
\hline
\end{tabular}

\section{c）基底流量}

基底流量については, 観測デ一夕の解析から対象流域 の比流量を $1.0 \mathrm{~m}^{3} / \mathrm{s} / 100 \mathrm{~km}^{2}$ と推定し, シミュレーション に適用した.

\section{（5）シミュレーションに必要な諸係数の推定}

\section{a）集中型モデルのパラメータの推定}

本研究の降雨流出モデルにおける4つのパラメータ

（So，Sc， $\alpha, \mathrm{k}$ ）は，各小流域ごとに降雨デー夕と流量 データの解析から同定すべきであるが，今回は観測流量 データが全流域の出口におけるものしか得られなかった ため, 観測降雨データと全流域の出口における観測流量 データからパラメータを推定し9（表-2），それを全小 流域に適用した。

b）小流域のピーク到達時間 $T_{p}$ および流出の終息時間

\section{$\operatorname{Tr}$ の推定}

各小流域からの表面流および中間流のハイドログラフ を計算するには，ピーク到達時間 $\mathrm{T}_{\mathrm{p}}$ (分)および流出の 終息時間 Tr （分）を計算しなければならない. そのた め，縮尺5,000分の 1 の森林基本図をスキャナーでGISに 読み込み、幾何補正を行った後, 各小流域の流路の記載 のない区間の斜面延長 L1（m），平均勾配勾配I1 およ び流路の記載のある区間の延長 L2（m）, 平均勾配 I2 を等高線をもとに読み取り, Ramserの式とKerbyの式を 組み合わせた（7）式で流達時間 $\mathrm{Tc}$ (分) を求め, 式10)に代入してピーク到達時間 $\mathrm{T}_{\mathrm{p}}$ (分) を求めた.

$$
\mathbf{T}_{\mathbf{c}}=\left(\frac{2.2 \mathrm{~nL}_{1}}{\sqrt{\mathrm{I}_{1}}}\right)^{0.467}+0.02 \mathrm{~L}_{2}^{0.77} \mathrm{I}_{2}
$$

$$
T_{p}=\frac{D}{2}+0.6 T_{c}
$$

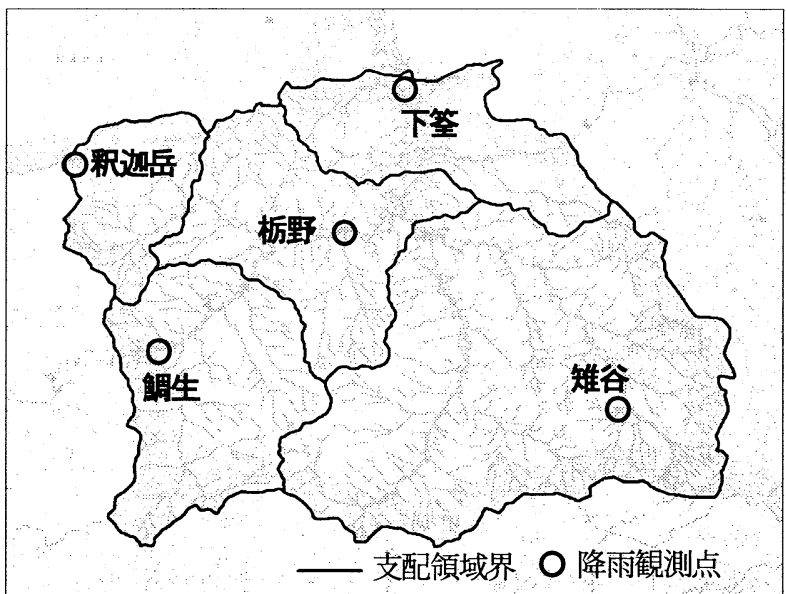

図-10 降雨観測点と支配領域

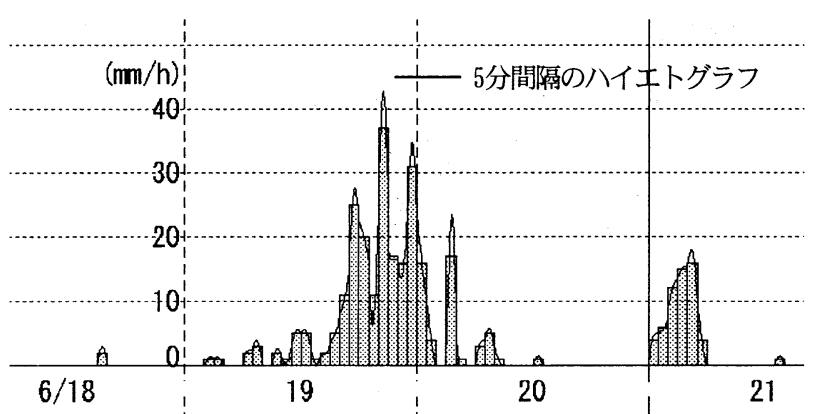

図-11 時間降雨デー夕の変換

ここで, $\mathrm{n}$ : マニングの粗度係数， $\mathrm{D}$ : ハイエトグラフ の時間間隔(分)である.

また，GISで地形図から各小流域の集水面積（A）を 読み取り，（5）式に代入して流出の終息時間 $\mathrm{Tr}$ を求 めた.

\section{（6）降雨デー夕の適用}

\section{a）降雨観測点亡支配領域}

鯛生、杤野、雉谷、下鉒および釈迦岳の降雨観測点の デー夕を採用し，観測点の支配領域をティーセン法を原 則として稜線で分割した（図-10）。

b）時間降雨データの5分間隔データへの变換

小流域の面積が1. $4 \mathrm{~km}^{2}$ の規模であるとそのピーク到達 時間 $T_{p}$ は約18分となる. したがって時間降雨デー夕を そのまま適用しても小流域の流出特性を十分に表現でき ない。5分間隔の観測降雨データを用いてシミュレー ションを行うことが望ましいが，現時点でそのような デー夕は入手できない. そのため, 単位時間内の降雨量 が保存されるように配慮しながら, 2次関数を用いて時 間降雨デー夕の連続的な雨量継続式を求め, そこから 5 分間隔のハイエトグラフを作成した（図-11）。

\section{（7）河道モデル}

Infoworks RSでは, 河道の物理的な形状を記述するた めに，河道の横断面を必要とする．その際，断面の間隔 は I を平均河床勾配としたとき，1/2I（m）以下にしな

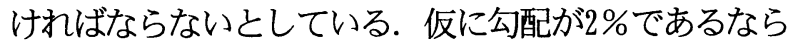




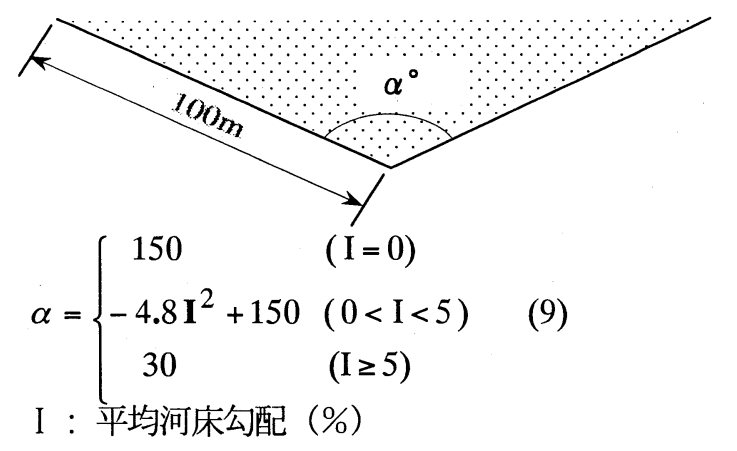

図-12 仮想三角形断面

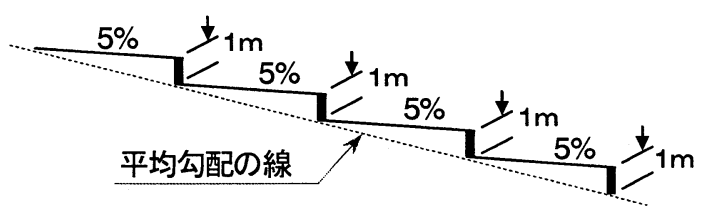

図-13 仮想落差工

ば，25m間隔となるが，そのようなデー夕を得ることは 現時点では不可能である.そこで河道を $1 \mathrm{~km}$ 間隔に分割し, その間の河床勾配は一定とし，かつその断面を図-12に 示すような三角断面とした. その頂角は侵食と堆積の影 響による河道の地形変化に応じて，勾配が緩くなるにつ れて頂角が広くなると仮定し，図-12中の式で表した. ただ，このような仮定の場合，1 kmおきに，勾配の変化 に伴い断面が急変することになるので、勾配変化点の手 前100mの地点から勾配変化点まで徐々に断面を変化させ る「馴致区間」を設けた。

なお，平均勾配が5\%を超えるような区間については， そのような急勾配の滑らかな河道は存在しないと考え, 図-13に示すような $5 \%$ の河床と落差 $1 \mathrm{~m}$ の落差工の組み 合わせで石と岩で構成された河床を模擬し, 適用した.

最後に，(4)で述べた方法で算出された小流域からの 流出ハイドログラフを, Infoworks上で各小流域の出口 に隣接する本流の河川断面に境界条件として入力するこ とにより，本研究における分布型モデルが完成し，シ ミュレーションを実施した.

\section{4. シミュレーションの結果}

降雨イベント6回を含む，2001年6月29日の正午から同 年7月21日零時までの20日間余を対象として連続シミュ レーションを行った. シミュレーションの計算に要した 時間は約23時間であった.

無降雨時の低流量条件でのシミュレーションを行うため に, 基底流量を増加しなければならなかった点を除けば, 最大 $17 \%$ の勾配をもつ急峻な山地でのシミュレーション に成功した.

結果の中から, 特徵的な 3 つの降雨イベントを抽出し, 下鉒ダムにおける計算流量と観測流量をグラフ化したも
のを図-14〜16に示す. 参考までに総降雨量と土壌の湿 潤状態を示す指標としての先行5日間の累積降雨量を付 記した.

（1）7月5日 21時からの降雨 総降雨量 $129 \mathrm{~mm}$ (24時間)
先行5日間の界皘降雨量

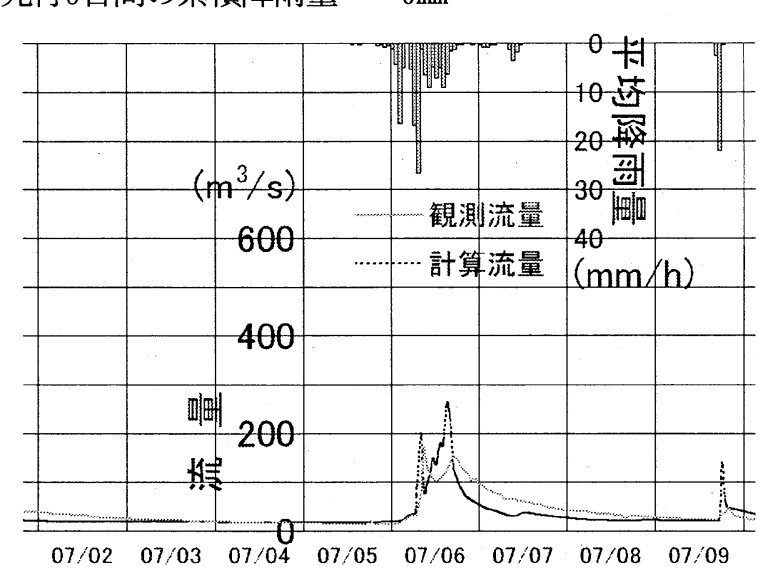

図-142001年7月5日付近のシミュレーション結果

（2）7月11日 3 時からの降雨

$\begin{array}{ll}\text { 総降雨量 } & 190 \mathrm{~mm} \text { (63時間) } \\ \text { 先行5日間の界皘降雨量 } 156 \mathrm{~mm}\end{array}$

先行5日間の累積降雨量 $156 \mathrm{~mm}$

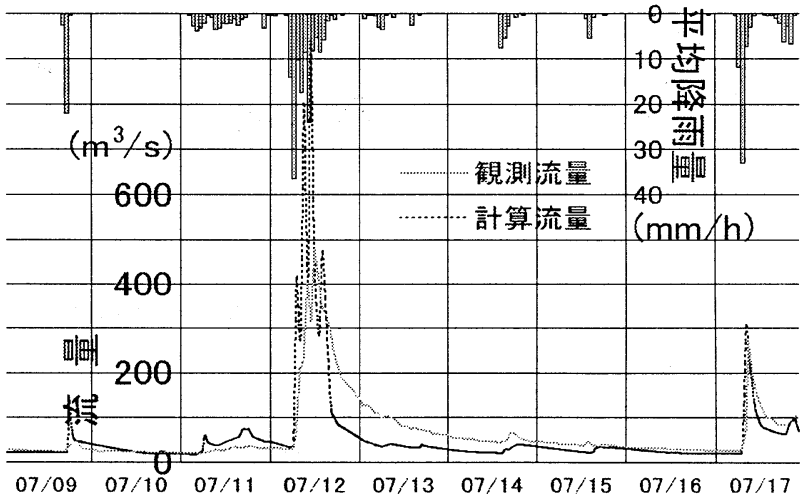

図-152001年7月11日付近のシミュレーション結果

（3）7月17日 6時からの降雨

$\begin{array}{lr}\text { 総降雨量 } & 84 \mathrm{~mm} \text { (25時間) } \\ \text { 先行5日間の累積降雨量 } 179 \mathrm{~mm}\end{array}$

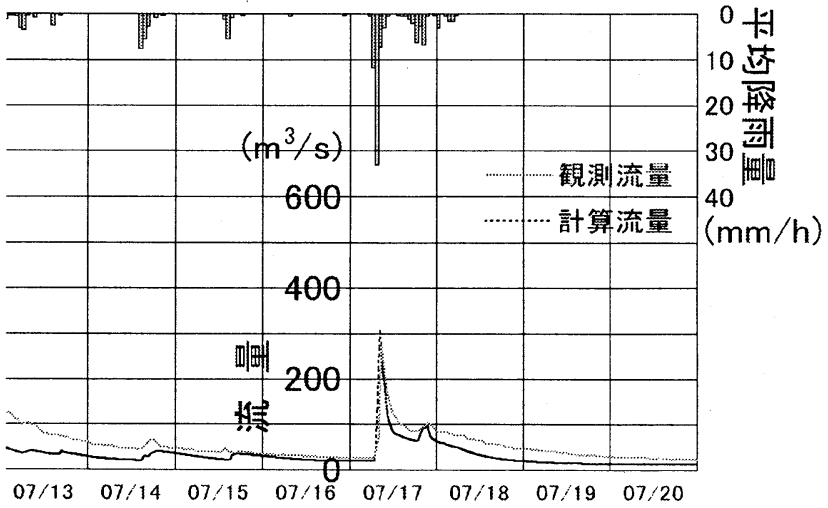

図-16 2001年7月17日付近のシミュレーション結果 


\section{5. 考察}

モデルのパラメータを変化させずに行ったシミュレー ション結果は, 降雨形態, 継続時間や土壌の湿潤状態の 変化に伴う観測流量の変動を，おおむね再現している. このことは本研究の基本的概念に誤りがないことを示し ており，また同定すべきパラメータが少ない降雨流出モ デルと操作性に優れた市販の河川シミュレーションソフ トで全体が構成されているため, 他の流域にも十分適用 可能であると考えられる.

しかしながら, 以下の二つの点において課題を残して いる.

（1）ピーク時の流量が過大に計算される傾向がある.

（2）ピーク到来後の流量の违減が過早に終息している. それらの原因としては, 以下のことが推定される.

(a) $182 \mathrm{~km}^{2}$ の集水面積を持つ本研究の対象流域に対し, 5ケ所の降雨観測点のデータでは, 降雨の分布性や 雨域の移動の影響をシミュレーションに反映できな いこと.

（b）時間降雨データを5分間隔のデータに変換してシ ミュレーションを行ったが，これは近似值に過ぎな いこと.

（c）流域の水理学的な状態を特定するための詳細な情報 が得られなかったことから, 全体流域におけるパラ メータをすべての小流域に適用したため, 各小流域 ごとの流出特性を十分に記述できていないこと.

\section{6. 今後の課題}

日本の短くてきわめて勾配が急な河川の流域をモデル 化するためには，本研究のように小規模の流域に分割せ ざるをえないが, 精度のよいシミュレーションのために は，それぞれの小流域での正確な降雨量を与えてなけれ ばならない。

また，パラメー夕は，それぞれの流域での観測された 降雨デー夕と流量デー夕の解析から同定されなければな らない. 今後はGISを利用して, より個別に小流域の特 性を考慮できるように研究を進めていく必要がある.

しかし，そのようなデータを取得するための観測は， 個人もしくは単独の研究機関では不可能であり, 公的な イニシアティブのもとに，長期間にわたり， 1 5km前 後の小流域を試験流域として，少なくとも5分間隔の降 雨と流量の観測がなされることが必要であると考える11).

そのような観測デー夕に基づいていろんな条件下での パラメータが同定され，同定されたパラメータと地形,
地質, 植生や土地利用との関係が求められれば，これか らの河川シミュレーションの精度は大幅に向上すると考 えられる.

なお，低流量時のシミュレーションを発散させること なく行うためには, 河床最深部に幅狭の仮想水路（実際 の都市河川で見られるような溝をもっと細くかつ深くし たもの）を追加することにより，より害際の流れを再現 できるものと考える.

謝辞: 本研究は, 文部科学省科学研究費 (基盤研究 $S$ ) 「建設副産物・廃棄物の管理と再利用システムの構築」

（課題番号14102027）の成果の一部である. また, 本研 究を行うに当たり，国土交通省九州地方整備局筑後川河 川事務所, 筑後川夕゙ム統合管理事務所, 下鉒ダム管理支 所, 大分県河川課及び農村整備課の協力を得た.ここに 記して謝意を表する.

\section{参考文献}

1) ロランド・プライス(市川 新 訳)：ハイドロインフォーマ ティックス: その社会と市場, 月間下水道, Vol.21, №.2, pp. 69-76, 1997

2) Chow, V. T. and D. R. Maidment, L. and W. Mays: Applied Hydrology, International edition, MacGraw-Hill, Inc. p. 281, 1988

3) Soil Conservation Service: Urban hydrology for small watersheds Technical release no.55, U.S. Department of Agriculture, 1975

4) Chow, V. T. and D. R. Maidment, L. and W. Mays: Applied Hydrology, International edition, MacGraw-Hill, Inc. p. 229, 1988

5) Chow, V. T. and D. R. Maidment, L. and W. Mays: Applied Hydrology, International edition, MacGraw-Hill, Inc. p. 149, 1988

6) Yamashita, M. and A. Ichikawa: A Study on the Unit Hydrographs with US SCS Method Regarding to Infiltrations, International Symposium on Disaster Mitigation and Basin-Wide Water Management, pp.168-177, 2003

7）鵜口 宗人・恩田 裕一・小杉 賢一朗・斉藤 哲生・森脇 寛 : 降雨流出における岩盤浸透流の影響に関する実験的研究, 水文・水資源学会誌，Vol.17，№. 3，pp. 252-263，2004

8) Linsley, R. K. Jr. and M. A. Kohler and J. L. H. Paulhus: Hydrology for Engineers, Third edition, MacGraw-Hill, Inc. New York. p. 210, 1958

9）山下 三男 : US SCS法に基づく分布型雨水流出モデルの構筑 に関する研究, 福岡大学大学院 平成15年度 修士学位論文, pp. 12-36, 2004

10) Chow, V. T. and D. R. Maidment, L. and W. Mays: Applied Hydrology, International edition, MacGraw-Hill; Inc. p. 229, 1988

11）市川 新・山下 三男：モデル論：「水・物質循環モデ ル・ソフトウエア博覧会2004」に参加して, 水文・水資源学 会誌, Vol.17, No.5, pp. 572-577, 2004

(2004.9. 30 受付) 